\title{
AGENTS, OLD AND NEW, CAUSING OCCUPATIONAL ASTHMA
}

\begin{abstract}
A sthma is common among adults of working age and affects $5-10 \%$ of the population worldwide. Occupational asthma has become a common work related respiratory disorder in the industrialised world. ${ }^{1}$ Blanc and Toren have shown that $9 \%$ of cases of adult asthma-including principally new onset asthma and, much more rarely, reactivation of pre-existing asthma-are attributable to occupational factors. ${ }^{2}$ Studies that have used information collected during military service suggest that occupational factors explain $25 \%$ of apparently new cases. ${ }^{3}$ From a practical point of view, addressing past and present occupational factors should be a priority in the assessment of adult onset asthma. In most cases, occupational exposures induce new onset asthma in a healthy subject, or workplace exposures may reactivate asthma in individuals who have been asymptomatic for years, or may aggravate pre-existing asthma. In each case, identifying which of these possibilities is true (that is, work related exposures as asthma inducers or asthma triggers) is relevant for the management of the disease, including prevention of additional cases, treatment, disability evaluation, and compensation.
\end{abstract}

Correspondence to: Cristina E Mapp MD, Dipartimento di

Medicina Clinica e Sperimentale, Sezione di Igiene e Medicina del Lavoro, Via Fossato di Mortara 64/b, 44100 Ferrara, Italy

mapp@ux1.unipd.it

\section{INCIDENCE RATES}

To date, more than 250 agents capable of causing occupational asthma have been reported. ${ }^{45}$ Substances that induce occupational asthma are classified as either high molecular weight allergens ( $>5 \mathrm{kDa}$ ) - usually protein derived allergens-or as low molecular weight compounds. It has been hypothesised that low molecular weight chemicals could act as haptens and combine with a body protein to form a complete antigen.

Since 1989, the SWORD (surveillance of work related and occupational respiratory disease) project has provided a consistent and reliable estimate of the incidence and pattern of occupational respiratory diseases in the UK. ${ }^{1}$ Occupational asthma continues to be the most reported respiratory disease, although its incidence is lower than in previous years, with an estimated 822 cases ( $27 \%$ of total cases). ${ }^{1}$ Reporting from previous years showed estimates of 1031 cases in 1997 and 1136 in 1996 . The most common identified agents causing asthma in cases reported in 1998 were enzymes (14\%), isocyanates (13\%), laboratory animals and insects (12\%), colophony fluxes and solders (9\%), flour (7\%), and glutaraldehyde (5\%). In 1997, incidence rates of occupational asthma were highest among workers in the manufacture of wood products, textiles, and food (particularly grain products and crustaceans), in the production of precious and non-ferrous metals, rubber goods, detergents and perfumes, and in mining. ${ }^{6}$ In the USA, in 1987 the National Institute for Occupational Safety and Health instituted SENSOR (sentinel event notification system for occupational risks), with the aim to identify and characterise new case reports of targeted occupational diseases. ${ }^{7}$ This system has led to reports of previously unrecognised causes of occupational asthma.

The analysis of data from the European Community Respiratory Health Survey (ECRHS) conducted in western European and other industrialised countries has provided new information on which jobs carry a high risk of asthma. ${ }^{8}$ The highest risk of asthma was shown for farmers, painters, plastic workers, cleaners, and agricultural workers. Excess asthma risk was associated with high exposure to biological dusts, mineral dusts, and gases and fumes. A consistent excess risk for cleaners and farmers in nearly all the 12 countries studied was shown. Under reporting of occupational asthma may be more common among women, since the risk of asthma attributable to occupational exposures among women was higher than expected. Occupational asthma can be suspected as the cause of asthma in $5-15 \%$ of asthmatic subjects. Given a mean prevalence of asthma of about $5 \%$, about $0.2-0.5 \%$ of young adults become asthmatics or have their asthma exacerbated because of their occupations. However, aggravation of pre-existing asthma by triggers at work should not be considered occupational asthma. Occupational asthma is a disease characterised by variable airflow limitation and/or airway hyperresponsiveness due to causes and conditions attributable to a particular occupational environment and not to stimuli encountered 
Box 1: Examples of jobs where sensitisation may be induced by the interaction between different agents

\begin{tabular}{|ll|}
\hline$f o b$ & Agent \\
\hline Spray painters & $\begin{array}{l}\text { Isocyanates, acrylates, amines, alkyd resins, } \\
\text { chromates, polyfunctional aziridine crosslinker (PFA) }\end{array}$ \\
$\begin{array}{l}\text { Health professionals } \\
\text { Bakers }\end{array}$ & $\begin{array}{l}\text { Latex, biocides, acrylates } \\
\text { Flour, grains, insect and enzyme products, storage } \\
\text { mites, plants }\end{array}$ \\
Food processors & $\begin{array}{l}\text { Plants, spices, enzymes, egg proteins } \\
\text { Animal derived allergens, arthropods, moulds, plants, } \\
\text { Farmers }\end{array}$ \\
fungicides \\
Hairdressers & $\begin{array}{l}\text { Persulfates, black henna, henna, red henna, sericin, } \\
\text { karaya, basic blue 99, azo dyes, dandruff }\end{array}$ \\
& \\
\hline
\end{tabular}

outside the workplace. Two types of occupational asthma are distinguished by whether they appear after a latency period: immunological and non-immunological (irritant induced asthma or reactive airways dysfunction syndrome (RADS)). Therefore activation of pre-existing asthma or airway hyperresponsiveness by non-toxic irritants or physical stimuli in the workplace is excluded by this definition.

\begin{tabular}{|c|c|}
\hline Agent & Occupation, use \\
\hline \multicolumn{2}{|l|}{ Animal derived allergens } \\
\hline Deer dander & Farmer \\
\hline Mink urine & Farmer \\
\hline Orangutan (Pongo pygmaes) & Zoo animal handler \\
\hline \multicolumn{2}{|l|}{ Crustacea, seafoods, fish } \\
\hline Clam and shrimp & Food processors \\
\hline Lobster and shrimp & Fishmonger shop \\
\hline Salmon & Processing plant \\
\hline Various fishes & Fish processors \\
\hline \multicolumn{2}{|l|}{ Arthropods } \\
\hline Panonychus citri & Citrus farmer \\
\hline Anisakis simplex (nematode) & Chicken breeder and fish monger \\
\hline Ground bugs & Bottling \\
\hline \multicolumn{2}{|l|}{ Moulds } \\
\hline Chrysonilia sitophila & Logging worker \\
\hline Rhizopus nigricans & Coal miner \\
\hline Botrytis cinerea & Winegrowers \\
\hline \multicolumn{2}{|l|}{ Plants } \\
\hline Fenugreek (Trigonella foemum graecum) & $\begin{array}{l}\text { Appetite stimulant and healing } \\
\text { agent }\end{array}$ \\
\hline Saccharomyces & Greenhouse worker \\
\hline $\begin{array}{l}\text { Flowers (various, including tulip, } \\
\text { hyacinth, Easter lilly, etc) }\end{array}$ & Flower industry \\
\hline Amaryllis & Greenhouse worker \\
\hline Spathe flowers & Floral worker \\
\hline $\begin{array}{l}\text { Stephanotis floribunda (Madagascar } \\
\text { jasmine) }\end{array}$ & Greenhouse workers \\
\hline Umbrella tree (Schefflera) & Landscape gardener \\
\hline Passiflora alata and Rhamus purshiana & Technician pharmacy \\
\hline Sarsaparilla root & Herbal tea worker \\
\hline Onion seeds (allium cepa, red onion) & Seed packing \\
\hline Fennel seed & Sausage processing \\
\hline Sesame seeds & Baker \\
\hline Grass juice & Gardener \\
\hline Asparagus & Food processor \\
\hline Mushroom & Office worker, cook \\
\hline Boletus edulis & Hotel manager \\
\hline Chicory (Cichorium intybua) & Vegetable wholesaler \\
\hline Phoenix canariensis & Gardener \\
\hline Saffron spice (Crocus sativus) & Saffron processors \\
\hline Aromatic herbs & Butcher \\
\hline Aniseed & Food industry \\
\hline Latex & $\begin{array}{l}\text { Glove and chewing gum } \\
\text { manufacture, health professional }\end{array}$ \\
\hline Esparto grass (Stipa tenacissima) & Stucco maker \\
\hline Cassia spp (Leguminosae) & $\begin{array}{l}\text { Manufacture of natural thickener } \\
\text { products }\end{array}$ \\
\hline \multicolumn{2}{|l|}{ Biologic enzymes } \\
\hline $\begin{array}{l}\text { Serratial peptidase and lysozyme } \\
\text { chloride }\end{array}$ & Pharmaceutical and lysozyme \\
\hline Pectinase and glucanase & Fruit processors \\
\hline Lactase & Pharmaceutical \\
\hline
\end{tabular}

The frequency of occupational asthma caused by classical agents such as isocyanates is still high, but there are less cases due to isocyanates and more cases due to latex, according to both the SWORD project and medicolegal statistics in Quebec, Canada. An interesting observation is that there are still new causes of occupational asthma from high molecular weight agents, but there are also emerging low molecular weight sensitisers such as acrylates. Finally, in some jobs, workers are exposed to several potential sensitisers (box 1), suggesting the possibility that sensitisation may occur through the interaction of several agents.

After review of the relevant published English language articles of the last five years, we identified several case reports of occupational asthma due to "unknown" allergens or to known agents in environments considered harmless (boxes 2 and 3). However, single cases may be inadequate to provide exact incidence rates of occupation asthma and to give a complete scenario of the problem. Many of these unusual allergens represent allergens one would never see in one's life time. The point is that asthma can be caused by agents that are not found on lists and databases. Therefore, we took into consideration the information obtained in the ECRHS

\begin{tabular}{|c|c|}
\hline Agent & Occupation, use \\
\hline \multicolumn{2}{|l|}{ Low molecular weight agents } \\
\hline \multicolumn{2}{|l|}{$\begin{array}{l}\text { Diisocyanates } \\
\text { Tryphenylmethane triisocyanate }\end{array}$} \\
\hline Tryphenylmethane triisocyanate & \\
\hline $\begin{array}{l}1,3 \text {-bis (isocyanatomethyl) } \\
\text { cyclohexane pre-polymer }\end{array}$ & $\begin{array}{l}\text { Automobile parts manufacture } \\
\text { plant }\end{array}$ \\
\hline $\begin{array}{l}\text { (BIC) (CAS n.75138-76-0; } \\
\text { 38661-72-2) }\end{array}$ & \\
\hline \multicolumn{2}{|l|}{ Hardeners } \\
\hline Tryglycid isocyanurate & Spray painter \\
\hline Polyfunctional aziridine & Hardener in paints \\
\hline Glutaraldehyde & Hardening agent in developer \\
\hline \multicolumn{2}{|l|}{ Anhydrides } \\
\hline Dioctyl-phatalate & Production of PVC \\
\hline \multicolumn{2}{|l|}{ Aliphatic amines } \\
\hline Aliphatic polyamines & Chemical factory \\
\hline \multicolumn{2}{|l|}{ Wood dust or bark } \\
\hline Oak (Quercus robur) & Carpenter \\
\hline Mukali (Angineria robusta) & Sauna building \\
\hline Ash (Fraxinus americana) & Sawmill \\
\hline Imbuia (Brazilian walnut) & Furniture \\
\hline Blackwood (Acacia melanoxylon) & Furniture \\
\hline \multicolumn{2}{|l|}{ Metals } \\
\hline Palladium & Assembly line \\
\hline Chromate salt & Cement floorer, plater, various \\
\hline Chromium and nickel & Electroplating \\
\hline Aluminium & Soldering \\
\hline \multicolumn{2}{|l|}{ Drugs } \\
\hline Piperacillin & Pharmaceutical \\
\hline Amoxicillin & Pharmaceutical \\
\hline Black henna & Herbal shop sales \\
\hline FD\&C blue dye n.2 & Food industry \\
\hline \multicolumn{2}{|l|}{ Biocides } \\
\hline Glutaraldheyde & $\begin{array}{l}\text { Hospital endoscopic unit, } \\
\text { endoscopy, radiology, paper } \\
\text { industry }\end{array}$ \\
\hline Isothizolinone & Chemical plant \\
\hline \multicolumn{2}{|l|}{ Fungicides } \\
\hline Urea formaldehyde & Resin, manufacture of foam \\
\hline Sulfites & Water plant, food processor \\
\hline Ninhydrin & Laboratory worker \\
\hline 1,2-benzisothizolin-3-one & Chemical worker \\
\hline \multicolumn{2}{|l|}{ Acrylates } \\
\hline Diacrylate & Autobody shop \\
\hline \multicolumn{2}{|l|}{ Synthetic material } \\
\hline Metal working fluid & Automobile plant \\
\hline \multicolumn{2}{|l|}{ Perfumes } \\
\hline $\begin{array}{l}\text { Mixture of natural and synthetic } \\
\text { substances, including volatile } \\
\text { oils, aldehydes, ethanol, etc }\end{array}$ & Salesperson \\
\hline \multicolumn{2}{|l|}{ Irritants } \\
\hline Tear gas & Teacher \\
\hline
\end{tabular}


survey, and the estimates obtained in countries such as the UK and Finland, ${ }^{9}$ where occupational asthma notification systems are complete. We then selected some of the common and novel causal agents with the aim of focusing the attention of readers on the size of the problem and on the possibility that an environment previously considered harmless may become a "sensitising" environment.

\section{Established and relatively new asthmagenics}

\section{Isocyanates}

Isocyanates have a wide application in the industrial and domestic environment, their annual worldwide production being in the range of three million tons. The isocyanate group $-\mathrm{N}=\mathrm{C}=\mathrm{O}$ reacts with compounds containing active hydrogen atoms. This property makes diisocyanates useful for the production of polyurethane foam, coating material, and adhesive manufacture. The most commonly used diisocyanate is toluene diisocyanate (TDI), a mixture of 2,4 and 2,6 isomers (80:20). Other diisocyanates include hexamethylene diisocyanate (HDI), naphthalene diisocyanate (NDI), isophorone diisocyanate, and methylene diphenyl diisocyanate (MDI). TDI, NDI, and MDI prepolymers are also available, and they have been shown to give rise to occupational asthma.

In spite of the recognised harmful health aspects of diisocyanates, they are widely used in most developed countries and therefore isocyanate induced asthma is one of the most studied forms of occupational asthma. To reduce the risk of sensitisation, industry started to introduce oligomers with high molecular weight.

Genetic factors might play a role in the development of isocyanate induced asthma. It has been shown that human leucocyte antigen (HLA) genes represent either a risk or a protective factor in the development of TDI induced asthma ${ }^{10}$; inheritance of the genetic marker might increase the risk of developing isocyanate induced asthma and might be necessary for the expression of this type of disease. Atopy and tobacco smoking do not predispose workers to higher risk in jobs where diisocyanates are used. Recently, it has been reported that smoking and atopy seemed to increase the odds of occupational asthma caused by isocyanates, but did not affect the estimate of risk associated with exposure. ${ }^{11}$ However, a small group of subjects was examined, smoking was associated with an increased risk of occupational asthma which was not significant, and atopy was based on history and not on skin prick tests.

Specific IgE antibodies against isocyanates are not constantly found in subjects with occupational asthma caused by isocyanates, leading most investigators to consider isocyanate induced asthma, particularly TDI induced asthma, as an example of IgE independent asthma. ${ }^{12}$ However, if they are found at high concentrations (radioallergosorbent test (RAST) score of $\geqslant 3$ ), they seem to be highly specific for the condition and therefore diagnostic of isocyanate induced asthma. ${ }^{13}$ Specific IgG antibodies seem to correlate better with the result of the specific inhalation challenge with isocyanates, ${ }^{14}$ but for some they are more a reflection of exposure than disease. Cell mediated immunity may play a crucial role and evidence has been provided by bronchoalveolar lavage and by bronchial biopsy studies. The pathology of the airways of subjects with isocyanate induced asthma is similar to that of non-occupational asthma, with cells such as $\mathrm{T}$ lymphocytes and eosinophils that exhibit signs of activation, and with thickening of the reticular layer of the basement membrane.

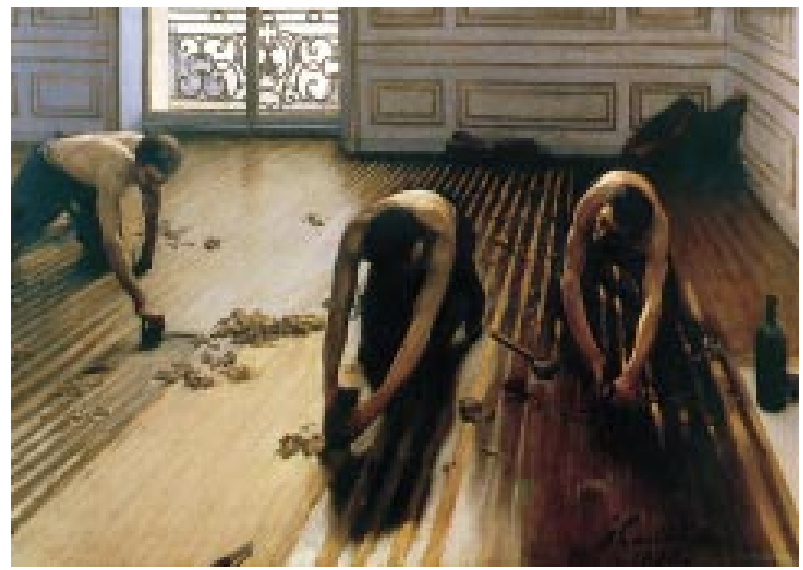

People working in certain wood industries, such as parquet flooring manufacturing, are at risk of developing occupational asthma as a result of exposure to wood dust and isocyanates. Painting by Caillebotte 1848-1894.

The spectrum of lung diseases that can be induced by diisocyanates is broad, including asthma with latency, irritant induced asthma, and hypersensitivity pneumonitis.

We do not know the precise mechanisms underlying isocyanate induced asthma, even though the immunological mechanism remains the more likely to occur. The main problem in the identification of the mechanisms involved is that we do not know what the antigen "isocyanate" looks like. The potential role of airway epithelium in isocyanate induced asthma has been recently documented. Wisnewski and colleagues identified specific human and skin epithelial cell proteins that become conjugated with HDI in vitro and in vivo. ${ }^{15}$

Another consideration is that, in some jobs (spray painters), subjects are currently exposed to several sensitising agents including isocyanates, acrylates, and amines, with the possibility of an interaction of several agents in causing sensitisation.

When a subject develops occupational asthma, whatever the cause, he should be immediately removed from the work environment. A pharmacological treatment with anti-inflammatory drugs (that is, inhaled glucocorticoids) must also be started immediately, and this behaviour is a rule once a diagnosis of occupational asthma has been established.

Latex

Natural rubber latex (NRL) allergy has been recognised since 1979, but only over the last decade has it been identified as a major cause of $\operatorname{IgE}$ mediated allergy in occupational and non-occupational environments. ${ }^{16}$ Allergic reactions range from urticaria to angioedema, anaphylaxis, rhinitis, and asthma. Contact dermatitis has also been reported.

Reasons for the increase of occupational asthma caused by latex include the increased use of NRL devices as a protective barrier against viral infections in the latter half of the 1980s, changes in manufacturing processes and growing methods of the rubber tree, and an increased recognition of NRL allergy by physicians and exposed subjects.

In the chemical industry the term latex is used to define any emulsion of polymers, including synthetic rubbers and plastics. NRL refers to products derived from the milky fluid produced by the laticifers of the tropical rubber tree Hevea braziliensis. Several of the proteins in NRL have been purified and sequenced.

Immediate hypersensitivity reactions caused by NRL are mediated through specific $\operatorname{IgE}$ antibodies directed against 
proteins contained in latex; in recent years, several potential allergens have been identified in Hevea latex and related finished products.

NRL is used in the manufacture of medical devices (gloves, catheters, anaesthetic masks, tubes, tourniquets, dental dams), as well as in the production of common articles (household gloves, baby pacifiers, toys, balloons, condoms, elastic straps, mattresses, tyres, adhesives, sport equipment). The routes of exposure are various, including skin and mucosal and serosal membranes. The protein allergens can bind to powder particles of gloves and become potent airborne allergens. Interestingly, the amount of airborne allergens in NRL correlates with the frequency of glove use. Secondary inhalation exposures can came from clothing and surgical scrub. The use of ethylene oxide to sterilise latex gloves may lead to additional sensitisation. However, because of different methods and reference extracts used for latex detection, different results concerning latex concentration may be obtained from the same air sample. Therefore an international standardisation of quantification of latex aeroallergen is urgently needed. ${ }^{17}$

Atopy is a risk factor for sensitisation to NRL although its predictive value is low. Hand eczema may also enhance the risk of sensitisation. Serious allergic reactions to foods (banana, kiwi, avocado, chestnut, and perhaps melon) occur more frequently in patients sensitised to NRL, and allergy to cross reacting foods may precede the onset of allergy to NRL.

NRL is ubiquitous in medical and non-medical environments, making it difficult to avoid exposure to this allergen completely. In hospital and dental care, gloves and special devices may be replaced by synthetic materials, but this measure has economic implications and requires time to be implemented. Non-powdered natural rubber gloves with lower protein content should be used by all staff members working in the environment of affected subjects. Once latex allergy has been established with objective methods, affected patients should find, when necessary, latex free environments.

Latex products are of common use, and buyers and consumers must be informed of the possibility of allergy, of the sources of exposure, and of the possibility of cross reactivity with certain foods. Allergic subjects should have an identification card or a medic Alert bracelet and should have an autoinjectable adrenaline (epinephrine) kit with clear written instructions on how to use it.

The natural history of latex allergy is unknown. However, despite cases where anaphylaxis and asthma are the starting events, in general, there is a progression from urticaria, to rhinoconjunctivitis, to asthma, and to anaphylaxis. Monitoring of subjects with skin problems or with rhinitis after exposure to latex may avoid the progression to the most serious diseases.

\section{Flour}

Flour and grains belong to a category of allergens that includes high molecular weight allergens such as laboratory animals and insects, enzymes, seafoods, gum, and latex, that act via an IgE mediated mechanism. In 1713, Bernardino Ramazzini described a respiratory disease among bakers and millers, and flour inhalation is still being reported as a common cause of occupational asthma today. Some indications from occupational disease registers suggest that occupational asthma in bakers is rising. The onset of asthma in bakers is usually preceded by nasal symptoms, such as rhinorrhoea, sneezing, and itchy eyes. The latency for sensitisation and development of occupational asthma to

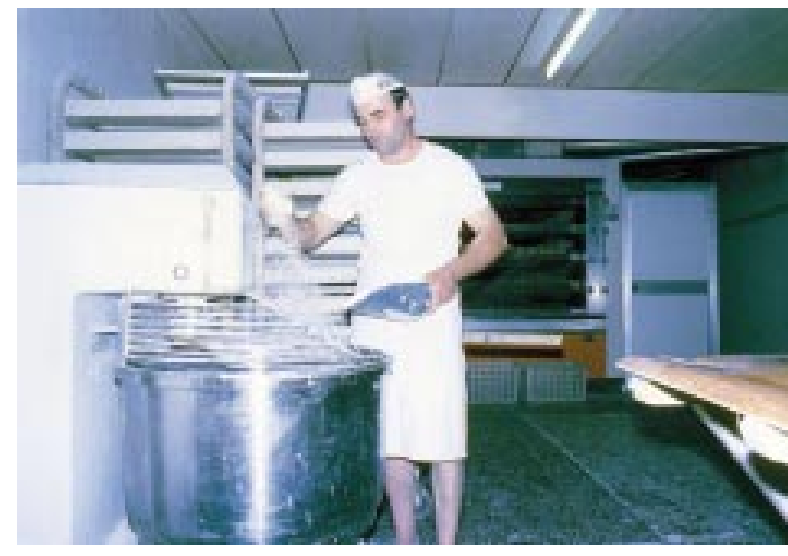

Bakers may be simultaneously exposed to an array of substances, such as flour, grains, insects, and enzyme products, which can cause occupational asthma.

flour is much longer than for animal derived allergens. In the workplace, bakers may be exposed to flour, grains, insects, and enzyme products simultaneously. Beside flour proteins, enzymes (that is, $\alpha$-amylase), other fungal species (Aspergillus, Alternaria, Cladosporium), and storage mites (Sitophilus granarius, Lepidoglyphus destructor, Acarus siro, Glycyphagus domesticus, Tyrophagus putrescentiae) and eggs, are all potential allergens. Soya is also emerging as an important cause of flour induced occupational asthma.

The mechanisms of occupational asthma in flour and grain workers appears to be similar (IgE mediated asthma) even though grain workers and farmers seem to become more sensitised to storage mites than to cereal flours. Almost all bakers with asthma are atopic subjects with positive skin tests to common allergens. The role of smoking in flour and grain asthma has not been completely clarified. The primary cause is the inhalation of flour proteins, mainly derived from wheat, rye, barley or soy. ${ }^{18}$ Epidemiological studies have found a strong correlation between the concentration of airborne flour and the development of work related symptoms, mainly in millers but not in bakers. Flour is the main product used, but differences in the antigen exposure levels have been found among bakeries.

Wheat and other cereals are composed of four classes of proteins: the water/salt soluble albumins and globulins, and the water/salt insoluble gliadins and glutenins which together are known as prolamins. ${ }^{19}$ Water/salt soluble allergens, which comprise $50 \%$ of the proteins in wheat flour, are associated with the development of cereal hypersensitivity in an occupational setting. However, the number of proteins involved in the development of cereal hypersensitivity is greater than previously believed and those individuals who are hypersensitive to water/salt soluble wheat proteins produce specific IgE to water/salt insoluble wheat proteins. The development of specific IgE to $\alpha$-gliadin may in part depend on the presence of cross reacting antibodies to water/ salt soluble flour allergens.

It is debated whether, as with laboratory animals, a family history of allergy or positive skin prick tests to common allergens (markers of underlying atopy) as sensitive or specific predictors of the development of occupational asthma, could be a useful screening test.

\section{Enzymes}

In 1969, Flindt showed that enzymes used in biological washing powder, apart from their potential to cause proteolytic effects on inhalation, were sensitisers and were causing allergic asthma. Proteolytic enzymes from Bacillus subtilis introduced in the 1960 s have been reported to be 
associated with asthma and nasal and ocular symptoms among workers involved in the manufacture of detergents. ${ }^{20}$ The observation that sensitisation capacity was not confined to proteolytic enzymes, and that the potential hazard was present for new enzymes such as lipases, cellulases or amylases was confirmed later.

Enzymes are recognised as respiratory sensitisers, and their allergenicity is independent of the class of enzyme and is a feature of their protein content. Many studies have shown that amylase is a cause of occupational asthma in bakers and pharmaceutical workers, but it is also a cause in hospital laboratory workers and in the detergent, food, and textile industries. Sensitisation and symptoms may occur independently of proteolytic activity, but proteolytic mechanisms may cause other relevant effects such as epistaxis or haemoptysis; a propensity to develop these proteolytic effects varies between different proteases, and susceptibility to such effects varies between people.

An increased interest in the role of $\alpha$-amylase used as a baking additive has been demonstrated by the growing number of studies on $\alpha$-amylase allergy in subjects with baker's asthma. Positive skin tests to fungal amylase of 5-9\% have been reported in bakers, and a positive and strong relation between $\alpha$-amylase allergen exposure levels in bakeries and specific sensitisation has also been shown. ${ }^{21}$ Atopic status was an important determinant of $\alpha$-amylase sensitisation. Other studies have shown that $24-34 \%$ of bakers with respiratory symptoms are sensitised to $\alpha$-amylase. Other enzymes beside $\alpha$-amylase have been reported to cause sensitisation in bakers, such as amyloglucosidase, cellulase, glucoamylase, hemicellulase, lipoxygenase, papain, pectinase, and xylanase. Most of these enzymes derive from Aspergillus species. Amylase exposure seems to be higher in large industrialised bakeries than in small bakeries.

Other sensitisers include the disaccharidase enzyme lactase, produced by Aspergillus oryzae and Aspergillus niger, which is used as a dough conditioner in bakeries and extensively used in the food and drug industries. Atopy was a risk factor for lactase skin sensitisation whereas duration of exposure and smoking were not found to be significant risk factors for lactase sensitisation.

Recently, evidence of occupational asthma and $\operatorname{IgE}$ sensitisation to cellulase in the textile industry and of occupational asthma induced by inhalation of peptidase and lysozyme extracts in the pharmaceutical industry has also been provided.

In summary, enzyme induced asthma occurs through an IgE mediated mechanism. Attempts to modify enzyme exposure by making particles less respirable have not entirely eliminated the risk of sensitisation. The use of enzymes in granules and encapsulation alone is insufficient to prevent enzyme induced allergy. ${ }^{22}$

It should be emphasised that the strategy to exclude atopic subjects is not easily applicable in industries utilising enzymes where atopy is a risk factor for sensitisation, and that it is more realistic to provide surveillance of both atopic and non-atopic subjects and to monitor workplace allergen concentrations.

\section{Glutaraldehyde}

Glutaraldehyde is used as a disinfectant or a sterilising agent in the hospital setting, and is often a constituent of radiographic developing solutions. It is also utilised as a fixative in histochemistry and electron microscopy and by the offshore oil and gas industries, to keep contaminating microbes low enough to avoid corrosion of the drilling machinery.

Most cases of occupational asthma have been reported among health care workers, particularly operating theatre and endoscopy nurses, and radiographers. Glutaraldehyde behaves like other low molecular weight chemicals (that is, isocyanates) in that specific antibodies can be detected in only a small percentage of symptomatic exposed workers and a poor correlation between specific IgE antibody and respiratory symptoms has been found. ${ }^{23}$

Prevention measures do not differ from those applied to all causes of occupational asthma. Use of periodic health questionnaires, focused on the upper and lower respiratory tract, could identify workers liable to develop occupational asthma caused by glutaraldehyde. Use of extraction fans, enclosure of the processes, respiratory protection, and training of personnel handling this low molecular weight aliphatic dialdehyde has been proposed as the first steps in any prevention strategy.

\section{Acrylates}

Acrylates have wide domestic as well as industrial uses (resins, glues, sealants, adhesives), and inhalation of vapours during their use can cause asthma. They are most often currently used in body car repair. Allergic contact dermatitis caused by acrylate compounds (acrylates, methacrylates, and epoxy acrylates) is common in dental personnel. Complaints about work related respiratory and conjunctival symptoms are also frequent. Acrylates constitute an important hazard for dental workers.

In the past, asthmatic reactions have been described after exposure to ethylcyanocrylate instant glue, and to methacrylate and cyanocrylates. More recently, artificial nail makers, cosmeticians, and health professionals have been recognised as being at risk.

Ninhydrin, a chemical laboratory reagent used in the detection of free amino and carboxyl groups in proteins and peptides, caused rhinitis followed after six months by asthma in a laboratory technician through an $\operatorname{IgE}$ mediated mechanism.

The industrial hardener polyfunctional aziridine (PFA) is synthesised from two components: aziridine, and trimethylolpropane triacrylate (TMPTA) or pentaerythritol triacrylate. PFA hardener may be contaminated with free $\mathrm{N}, \mathrm{N}$-dimethylethanolamine and propyleneimine, but not with free TMPTA.

To prevent acrylate sensitisation, adequate workplace ventilation is needed. Acrylates may be considered an emerging important cause of low molecular weight induced occupational asthma. ${ }^{24}$

\section{Conclusions}

The SWORD '98 report $^{1}$ has described the most commonly identified agents causing asthma and has also shown that asthma accounted for most of the cases of respiratory disease in chemical manufacture, mineral products manufacture, motor vehicle manufacture (spray painters and assemblers), and food processing industry as a result of flour and enzyme sensitisation. Latex and glutaraldehyde exposures accounted for high rates of respiratory diseases seen in health care workers. Wood products manufacture and textile and clothing manufacture showed a reduction in incident cases (506 cases per million workers in 1997 to 34 cases per million workers in 1998, and 397 cases per million workers in 1997 to 65 cases per million in 1998, respectively). 


Box 4 : Key points
Occupational asthma is a commonly reported respiratory
disease
Occupational asthma can be caused by agents that are
not found on lists and databases
Commonly identified agents causing occupational asthma:
-isocyanates (13\%)
-laboratory animals and insects (12\%)
-colophony fluxes and solders $(9 \%)$
-flour ( $7 \%)$
- glutaraldehyde $(5 \%)$
Jobs with high risk of asthma:
-farmers
-painters
- plastic workers
- cleaners
-agricultural workers

Irritant induced asthma or RADS may occur after single or multiple exposures to non-specific irritants at high concentrations. Inhalation accidents were common, and the responsible agents were gaseous agents and combustion products $(49.8 \%$ cases), organic chemicals (23\%), and inorganic chemicals including acids $(15.1 \%)$. It is likely that irritant induced asthma is not always recognised and it is still unknown whether exposure to "low" dose irritants will ever give rise to asthma. The ECRHS ${ }^{8}$ has reported a higher risk of asthma for farmers, painters, plastic workers, agricultural workers, and cleaners. Cleaners had an excess risk of asthma in 11 of 12 countries examined. Interestingly, housewives, who share some of the exposures of cleaners, particularly to irritant gases, detergents, cleaning materials, and indoor allergens, had a small but significant excess risk of asthma.

In conclusion, occupational asthma caused by classical agents (for example, isocyanates) is still frequent. Although we might have expected more low molecular weight agents to cause occupational asthma, high molecular weight agents continue to play a major role. Secondly, several jobs and workplaces expose workers to more than one sensitising agent, raising the possibility of an interaction of several agents causing sensitisation. Thirdly, chemicals such as prepolymers, used in the place of well know sensitisers such as isocyanates, have been recognised as causing occupational asthma. Finally, occupational asthma can be caused by agents that are not found on lists and databases.

Thus, surveillance systems are needed for the implementation of preventive measures and for the identification of aetiologic agents. ${ }^{25}$

The author is grateful to Professor Moira Chan-Yeung and to Professor Jean-Luc Malo for the helpful and stimulating suggestions in the preparation of this manuscript. Supported in part by the Minister of University and Scientific Research (MURST $60 \%, 40 \%$ ), by the Minister of Labour and Welfare, and by ARCA.

\section{References}

1 Meyer JD, Holt DL, Cherry NM, et al. SWORD '98: surveillance of work-related and occupational respiratory disease in the UK. Occup Med 1999;49:485-9.

- This paper reports on the 1998 SWORD results and findings. The scheme uses systematic reporting from chest physicians to provide a picture of the incidence and patterns of occupational respiratory disease in the UK, along with information on industry, occupation, and suspected aetiology.

2 Blanc PD, Toren K. How much adult asthma can be attributed to occupational factors? Am J Med 1999;107:580-7.
This paper reviews and synthesises the literature in order to make a reliable estimate of the attributable risk of adult asthma that is associated with workplace exposures.

3 Katz I, Moshe S, Sosna J, et al. The occurrence, recrudescence and worsening of asthma in a population of young adults. Impact of varying types of occupation. Chest 1999;116:614-8.

4 http://asmanet.com

- A fantastic web site of agents causing occupational asthma, developed by Henriette Dhivert from Montpellier who is currently updating the site.

5 Chan-Yeung M, Malo J-L. Tables of major inducers of occupational asthma. In : Bernstein IL, Chan-Yeung M, Malo J-L, Bernstein DI, eds. Asthma in the workplace, part IV. New York: Marcel Dekker, 1999:683-721.

The common goal of individual contributors in this book was to prepare an authoritative, educational resource for primary care physicians, occupational health specialists, allergists, and respiratory specialists. Detailed information about specific agents that induce asthma or asthma-like diseases has been reported. Compendiums on comprehensive tables that list the major sensitisers, on the US national occupational exposure survey (NOES) data base, and on the French telematic information system (MINITEL) on occupational asthma, have also been reported.

6 Ross DJ, Keynes HL, McDonald JC. SWORD '97: surveillance of work-related and occupational respiratory disease in the UK. Occup Med 1998:48:481-5.

7 Matte TD, Hoffman R, Rosenman KD. Surveillance of occupational asthma under the SENSOR model. Chest 1990;98:735-88.

8 Kogevinas M, Antò JM, Tobias A, et al. Occupational asthma in Europe and other industrialised areas: a population-based study. Lancet 1999;353:1750-4.

- The survey was done in western European and other industrialised countries, and incorporated information from random samples of the general population of young adults in selected areas. The aim was to verify which occupations carry a high risk of asthma, and to estimate the proportion of asthma cases in the general population attributable to occupational exposures.

9 Karjalainen A, Kurppa K, Virtanen S, et al. Incidence of occupational asthma by occupation and industry in Finland. Am J Ind Med 2000;37:451-8.

10 Mapp CE, Beghè B, Balboni A, et al. Association between HLA genes and susceptibility to toluene diisocyanate-induced asthma. Clin Exp Allergy 2000;30:651-6.

11 Meredith SK, Bugler J, Clark RL. Isocyanate exposure and occupational asthma: a case-referent study. Occup Environ Med 2000;57:830-6.

12 Mapp CE, Saetta M, Maestrelli P, et al. Occupational asthma. In: Mapp CE, ed. Occupational lung disorders. Eur Respir Mon 1999;11:255-85.

- This monograph reviews general epidemiological, clinic, diagnostic, and regulatory aspects of occupational lung disorders, with the aim of providing the reader with a general background on the identification and quantification of exposure, on epidemiological research, diagnosis, management, prevention, regulatory issues, and medicolegal problems concerning the most relevant occupational lung diseases, including occupational asthma. Mechanisms, definitions, and clinical findings have also been described.

13 Tee RD, Cullinan P, Welch J, et al. Specific IgE to isocyanates: a useful diagnostic role in occupational asthma. J Allergy Clin Immunol 1998;101:709-15.

14 Park HS, Kim HY, Nahm DH, et al. Specific IgG, but not specific lgE, antibodies to toluene diisocyanate-human serum albumin conjugate are associated with toluene diisocyanate bronchoprovocation test results. $J$ Allergy Clin Immunol 1999;104:847-51.

15 Wisnewski AV, Srivastava R, Herrick $C$, et al. Identification of human lung and skin proteins conjugated with hexamethylene diisocyanate in vitro and in vivo. Am J Respir Crit Care Med 2000;162:1-7.

16 Vandenplas $\mathrm{O}$, Charous BL, Tarlo SM. Latex allergy. In: Bernstein IL, Chan Yeung M, Malo J-L, Bernstein DI, eds. Asthma in the workplace, part III. New York: Marcel Dekker, 1999:425-44.

17 Baur X, Chen Z, Allmers H. Can a threshold limit value for natural rubber latex airborne allergens be defined? J Allergy Clin Immunol 1998;101:24-7.

18 Sandiford CP. Cereal-induced occupational asthma [editorial]. Clin Exp Allergy 1996;26:128-31.

19 Sandiford CP, Tatham AS, Fido R, et al. Identification of the major water/salt insoluble wheat proteins involved in cereal hypersensitivity. Clin Exp Allergy 1997;27:1120-9.

20 Flindt MLH. Biological miracles and misadventures: identification of sensitization and asthma in enzyme detergent workers. Am J Ind Med 1996;29:99-110. 
A very interesting story! Misinformation probably also impedes identification of a sensitising agent present in the workplace.

21 Houba R, Dick J, Heederik J, et al. Exposure-sensitization relationship for $\alpha$-amylase allergens in baking industry. Am J Respir Crit Care Med 1996;154:130-6.

22 Cullinan P, Harris JM, Newman Taylor AJ, et al. An outbreak of asthma in a modern detergent factory. Lancet 2000;356:1899-900.

23 Curran AD, Burge PS, Wiley K. Clinical and immunologic evaluation of workers exposed to glutaraldehyde. Allergy 1996;51:826-32.

24 Weytjens $\mathrm{K}$, Cartier $\mathrm{A}$, Lemière $\mathrm{C}$, et al. Occupational asthma to diacrylate. Allergy 1999;54:287-96.

25 Nordman $\mathrm{H}$, Karjalainen, Keskinen $\mathrm{H}$. Incidence of occupational asthma: a comparison by reporting systems. Am J Ind Med 1999;1(suppl):130-3.

- This paper describes source and quality of data on the incidence of occupational asthma obtained from Finland, Sweden, UK, USA, and Quebec, Canada. Comparative incidences are reported and also incidences by occupation are included.

\section{QUESTIONS (See answers on page 290)}

For each question, indicate which answers are true and which are false.

(1) In relation to the frequency of occupational asthma:

(a) Less than $1 \%$ of cases of adult asthma are attributable to occupational factors

(b) Up to $25 \%$ of new asthma cases in adults are explained by occupational factors

(c) Around 100 agents capable of causing occupational asthma have been identified

(d) Occupational asthma is the most commonly reported respiratory disease in the SWORD surveillance scheme (e) $0.2-0.5 \%$ of young adults become asthmatic or have their asthma exacerbated because of occupational exposures

(2) The definition of occupational asthma:

(a) Does not include activation of pre-existing asthma or airway hyperresponsiveness due to physical stimuli at work

(b) Includes immunological and non-immunological forms

(c) Is a disease characterised by variable airflow limitation and/or airway hyperresponsiveness due to causes attributable to a particular occupational environment

(d) Includes aggravation of pre-existing asthma by triggers at work

(3) Among causes of occupational asthma:

(a) Latex is a more commonly reported cause of occupational asthma than isocyanates in the UK

(b) Most cases of isocyanate occupational asthma have specific IgE antibodies

(c) The frequency of occupational asthma in bakers is rising

(d) Most cases of occupational asthma due to glutaraldehyde have been reported in health care workers

(e) Irritant induced asthma can occur after single exposure to irritants at high concentration

(4) Mechanisms of occupational asthma:

(a) Low molecular weight sensitisers may act as haptens and bind to plasma proteins

(b) Sensitisation to proteins relates to their proteolytic actions

(c) Occupational asthma in grain and flour workers is usually IgE mediated

(d) There is cross-reactivity between natural rubber latex and foods including bananas and avocados

(e) Cell mediated immunity is not relevant in isocyanate asthma

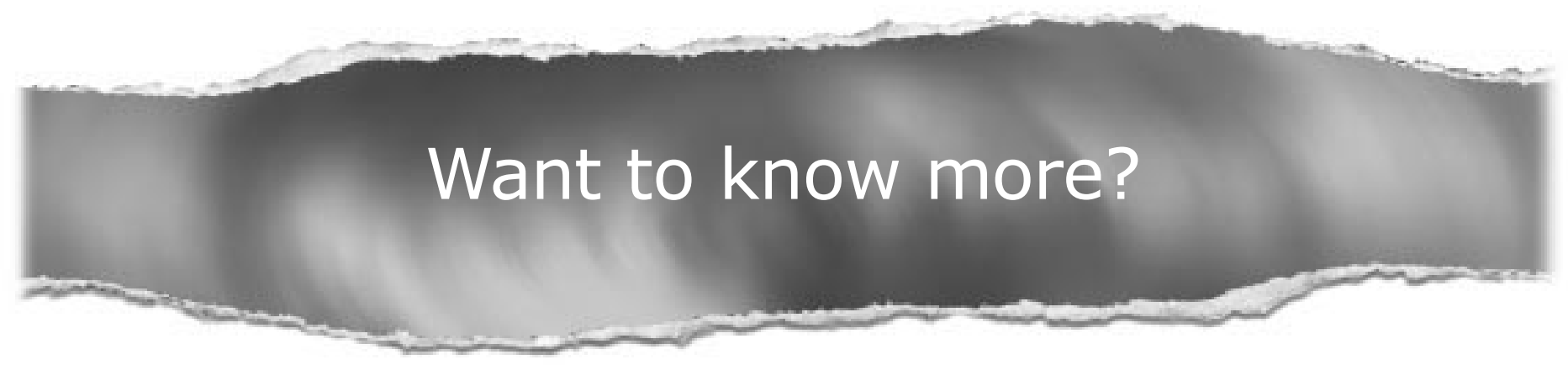

\section{Data supplements}

Limited space in printed journals means that interesting data and other material are often edited out of articles; however, limitless cyberspace means that we can include this information online.

Look out for additional tables, references, illustrations.

www.occenvmed.com 